\title{
PERDAGANGAN YANG ADIL DALAM ISLAM
}

\author{
Oleh : Fithri Azizah \\ Jurusan Perbankan Syariah, Fakultas Ekonomi dan Bisnis Islam, Universitas Islam Negeri \\ Alauddin Makassar \\ firhriazizah@gmail.com
}

\begin{abstract}
Abstrack
Trade is something that is so familiar to citizens of any country, especially Indonesia. Because trade is the route used to spread Islam in Indonesia. So, of course, trading has existed since ancient times. Trading or buying and selling is an economic activity in which sellers and buyers make agreements to mutually benefit both parties. Starting a business for a seller is not an easy thing. There must be such a thing as a mature strategy and of course capital. The mechanism for sellers is usually to spend a little capital and then make a lot of profit. So everything will be done to get a lot of profit. But nowadays there are many irrensposible people like doing unfair things to get a lot of profit. But also we as servants of Allah who believe, of course, must be on his straight path. Not tempted by any of it. Because the trade in Islam is really important is not looking for big profits, but has made buyers feel satisfied. If we do good to fellow humans, Allah willing, will repay our kindness.
\end{abstract}

Keywords: trading, buying, selling, profit

\begin{abstract}
Abstrak
Perdagangan merupakan sesuatu hal yang tidak asing lagi bagi warga negara manapun terutama Indonesia. Sebab perdagangan merupakan jalur yang digunakan untuk menyebarkan agama Islam di Indonesia. Jadi perdagangan tentu saja sudah ada sejak zaman dahulu. Perdagangan atau jual beli merupakan suatu kegiatan ekonomi dimana penjual dan pembeli melakukan kesepakatan hingga saling menguntungkan kedua belah pihak. Untuk memulai sebuah bisnis bagi seorang penjual bukanlah merupakan sesuatu hal yang mudah. Harus ada yang namanya strategi yang matang dan tentu saja modal. Mekanisme bagi penjual biasanya
\end{abstract}


mengeluarkan modal yang sedikit lalu untung yang banyak. Sehingga segala hal akan dilakukan demi mendapatkan untung yang banyak. Tapi masa sekarang banyak orang yang tidak bertanggung jawab seperti melakukan hal yang tidak adil demi mendapatkan keuntungan yang banyak. Tetapi juga kita sebagai hamba Allah yang beriman tentu saja harus berada di jalan-Nya yang lurus. Tidak tergoda oleh apapun itu. Karena sesungguhnya perdagangan di dalam Islam yang penting bukanlah mencari keuntungan yang besar, tetapi telah membuat pembeli merasa puas. Jika kita berbuat baik sesama manusia, InsyaAllah Allah akan membalas kebaikan kita itu.

Kata kunci : perdagangan, jual, beli, untung

\section{PENDAHULUAN}

Seperti yang kita ketahui kita sudah tidak asing lagi dengan kata perdagangan, bagaimana tidak perdagangan adalah suatu lapangan kerja yang sangat banyak dilakukan oleh orang-orang untuk bertahan hidup. Terutama lagi perdagangan juga merupakan jalur yang digunakan Nabi Muhammad saw. untuk menyebarkan agama kita yaitu agama Islam. Perdagangan sudah ada sejak zaman dahulu kala dan masih sangat bertahan sampai sekarang. Hal tersebut dikarenakan kita selalu membutuhkan sesuatu, mau itu barang atau makanan dan sebagainya. Dan hal tersebut tentunya diperjual belikan dalam sebuah perdagangan. Jadi tidak heran kita maupun sebagai penjual atau pembeli saling membutuhkan. Penjual membutuhkan uang dari apa yang ia jual, dan begitupun dengan pembeli membutuhkan apa yang ia beli. Jadi sama-sama menguntungkan bukan?

Tetapi sebagai penjual, kadangkala kita tidak mengalami keuntungan terus-menerus. Kadang pelanggan ramai, kadang sepi. Dengan begitu sebelum melakukan yang namanya suatu bisnis kita harus melakukan strategi yang benar-benar matang. Bagaimana kita akan mengahadapi hal-hal yang akan dihadapi ke depannya. Agar tidak mengalami suatu kerugian yang besar sehingga menyebabkan bangkrut. Apalagi di masa sekarang di masa pandemi ini, kita melakukan semua hal sangat berbanding terbalik dengan dulu. Dimana semua dulunya apa-apa kita lakukan di luar rumah. Tapi saat ini kita harus melakukan semua itu hanya di rumah saja. Tapi karena masa pandemi ini sudah berlalu satu tahun, jadi mungkin kita sudah terbiasa dengan kebiasaan baru ini. 
Hukum perdagangan atau jual beli dalam Islam yaitu mubah atau boleh. Dalam islam sebenarnya ketika melakukan jual beli, penjual tidak perlu keuntungan yang banyak, yang terpenting adalah ketika pembeli merasa puas atas apa yang ia beli. Maka dari itu kita harus melakukan sebuah perdagangan yang adil, dimana yaitu adanya keuntungan yang didapatkan oleh kedua pihak. Tidak ada tipu-menipu baik itu dari penjual bisa juga dari pembeli. Sebagaimana hadis Rasulullah saw. :

"Berdaganglah kalian dengan jujur dan amanat, niscaya orang-orang yang jujur dan orangorang yang mati syahid akan bersama dengan Nabi.” (HR. Al-Hakim dan Tirmidzi)

"Sesungguhnya sebaik-baik penghasilan ialah penghasilan para pedagang yang mana apabila berbicara tidak bohong, apabila diberi amanah tidak khianat, apabila berjanji tidak mengingkarinya, apabila membeli tidak mencela. Apabila menjual tidak berlebihan (dalam menaikkan harga), apabila berhutang tidak menunda-nunda pelunasan dan apabila menagih hutang tidak memperberat orang yang sedang kesulitan.” (Diriwayatkan oleh Al-Baihaqi).

Lalu kemudian Nabi saw. pernah ditanya, “profesi apakah yang paling baik?” maka beliau menjawab, bahwa profesi terbaik yang dikerjakan oleh manusia adalah segala pekerjaan yang dilakukan dengan kedua tangannya dan transaksi jual beli yang dilakukannya tanpa melanggar batasan-batasan syariat. (Hadits shahih dengan banyaknya riwayat, diriwayatkan Al Bazzar 2/83, Hakim 2/10; dinulkil dari Taudhihul Ahkam 4/218-219).

\section{PEMBAHASAN}

\section{Pengertian Perdagangan Secara Umum}

Menurut Wikipedia, perdagangan atau perniagaan adalah kegiatan tukar menukar barang atau jasa atau keduanya yang berdasarkan kesepakatan bersama bukan pemaksaan. Pada masa awal sebelum uang ditemukan, tukar menukar barang dinamakan barter yaitu menukar barang dengan barang. Pada masa modern perdagangan dilakukan dengan penukaran uang. Setiap barang dinilai dengan sejumlah uang. Pembeli akan menukar barang atau jasa dengan sejumlah uang yang diinginkan penjual. Dalam perdagangan ada orang yang membuat yang disebut produsen. Kegiatannya bernama produksi. Jadi, produksi adalah kegiatan membuat suatu barang. Ada juga yang disebut distribusi. Distribusi adalah kegiatan mengantar barang dari produsen ke konsumen. Konsumen adalah orang yang membeli barang. Konsumsi adalah kegiatan menggunakan barang dari hasil produksi. 
Perdagangan atau biasa disebut jual beli merupakan sesuatu hal yang sudah lumrah di masyarakat luas. Kegiatan dagang merupakan kegiatan yang sudah ada sejak dahulu kala. Sehingga bisa dibilang kegiatan ini sangat melekat pada manusia, karena kita sudah tidak bisa dipisahkan dengan kegiatan jaul beli. Jual beli merupakan kegiatan menukar barang demi mendapatkan keuntungan masing-masing. Setiap orang pasti selalu saja membutuhkan yang namanya barang atau jasa. Jadi lewat kegiatan jual beli ini orang-orang dapat memenuhi keinginan yang diinginkannya. Dengan begitu jual beli sudah melekat pada hidup kita.

Seiring berjalannya zaman, proses jual beli terus menerus terperbaharui sesuai zaman. Seperti zaman dahulu, dimana belum ada yang namanya uang, jadi orang-orang hanya saling menukarkan barang yang mereka punya. Tapi ketika uang sudah ada, orang-orang membayar barang dengan uang tentunya. Dulu orang-orang melakukan transaksi atau membeli barang dengan bertemu, tapi karena sekarang dengan meningkatnya ekonomi perlahan berubah. Saat ini kita juga bisa hanya melihat barang-barang melalui ponsel pintar yang dimiliki lalu kemudian memilih barang yang dimiliki dan menunggu barang itu dikirimkan. Proses pembayarannya biasa dilakukan ketika barang itu sampai atau juga bisa dengan cara mentransfernya. Proses tersebut disebut proses jual beli online. Zaman sekarang merupakan zaman dimana semuanya dapat dilakukan hanya melaui ponsel. Dengan begitu membuat kita lebih mudah dalam melakukan hal apapun.

\section{Pengertian Perdagangan Menurut Islam}

Perdagangan atau jual beli dalam islam merupakan kegiatan yang diperbolehkan bagi siapapun. Jual beli menurut bahasa yaitu bahasa arab adalah Al Bay yang artinya adalah pertukaran atau mudalabah. Jual beli dalam Islam adalah pertukaran suatu barang untuk mendapatkan barang yang lain atau juga untuk mendapatkan kepemilikan barang tersebut melalui sebuah kesepakatan.

Adapun pengertian perdagangan menurut beberapa ahli fiqih, sebagai berikut :

1. Menurut ahli fikih madzhab Hanafiyah, perdagangan adalah menukarkan harta dengan harta melalui tata cara tertentu, atau mempertukarkan sesuatu yang disenangi dengan sesuatu yang lain melalui tata cara tertentu yang dapat dipahami sebagai al-Ba'I, seperti ijab dan Ta'athi (saling menyerahkan).

2. menurut Imam Nawawi, perdagangan adalah mempertukarkan harta dengan harta untuk tujuan pemilikan. 
3. Menurut Ibn Qodamah, perdagangan adalah mempertukarkan harta dengan harta untuk tujuan pemilikan dan menyerahkan milik.

Dalam Islam proses jual beli merupakan kegiatan mempermudah untuk memenuhi kebutuhan bagi siapapun. Maka dari itu jual beli sebenarnya sangat penting dalam Islam, sehingga harus adanya sebuah aturan dan larangan dalam jual beli. Aturan dan larangan tersebut tentunya terdapat di dalam ayat suci Al- Qur'an. Sebagaimana dalam surah AlBaqarah ayat 254, yang berbunyi :

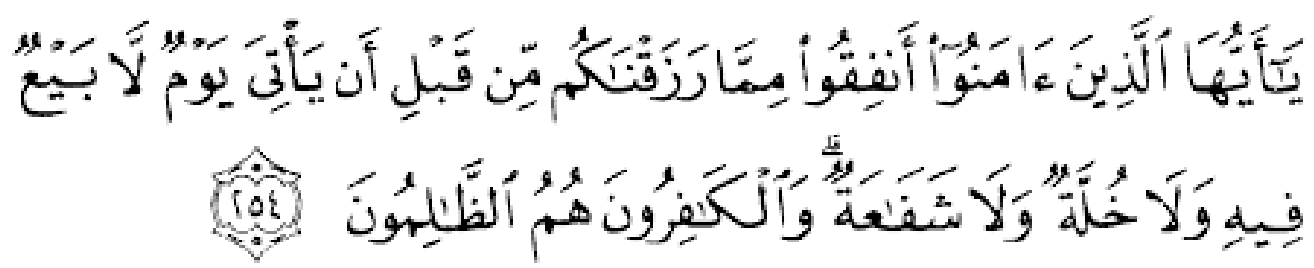

"Hai orang-orang yang beriman, belanjakanlah (di jalan Allah) sebagian rezeki yang telah kami berikan kepadamu sebelumdatang hari yang pada hari itu tidk ada lagijual beli dan tidak ada lagi syafa'at. Dan orang-orang kafir itulah orang-orang yang zalim” (QS.A1Baqarah:254)

Di dalam Islam, ada dua prinsip perdagangan yaitu suka sama suka dan tidak ada yang dirugikan. Dalam Islam, kita tidak dibolehkan untuk memaksakan kehendak orang lain. Karena masing-masing orang pasti mempunyai hak atau pilihannya. Maka dari itu kegiatan jual beli harus dari keinginan si penjual maupun pembeli sehingga tidak adanya kerugian oelh dua belah pihak.

\section{Rukun Dan Syarat Jual Beli Dalam Islam}

Dalam hidup pasti selalu saja ada yang namanya aturan baik dimanapun itu berada. Kita terkadang tidak bisa melakukan suatu hal dengan semaunya. Hal tersebut dilakukan agar kita selalu melakukan hal-hal dengan benar sehingga tidak lalai. Maka dari itu, jual beli juga mempunyai yang namanya atura-aturan, agar tidak terjadi hal-hal yang melalaikan. Jadi, ada yang namanya rukun dan syarat jual beli.

Adapun berikut rukun jual beli dalam Islam, yaitu :

1. 'aqid (subjek jual beli), yaitu penjual dan pembeli

2. ma'qud alaih (objek jual beli), yaitu barang dan harga dagangan 
3. mahal al-'aqdi (sighat), yaitu ijab dan qabul

4. maudhu 'al-'aqdi (tujuan jual beli), yaitu untuk memenuhi kebutuhan masig-masing baik penjual maupun pembeli.

Selain rukun, jual beli juga mempunyai yang namanya syarat. Adapun berikut syarat jual beli dalam Islam, yang telah dikutip dari buku Fiqh Muamalah oleh Drs. Harun, MH yaitu :

1. Penjual (subjek jual beli)

Penjual dan pembeli harus berakal, baligh, dan rusyd. Adapun anak kecil yang sudah mumayyiz hukumnya adalah sah. Mumayyiza disini artinya dapat membedakan mana yang benar dan mana yang salah.

2. Barang (objek jual beli)

$\checkmark$ Barang ada wujudnya ketika transaksi (akad). Jika barang tersebut tidak ada ketika akad, namun pihak penjual menyatakan kesanggupannya untuk mengadakan barang itu, misalnya di gudang.

$\checkmark$ Barang tersebut bermanfaat bagi manusia. Karena khamr, daging babi, dana narkoba tidak diperbolehkan untuk dijual.

$\checkmark$ Barang yang diperjual belikan sudah menjadi kepemilikan

$\checkmark$ Barang dapat diserahkan ketika akad.

3. Harga (objek jual beli)

$\checkmark$ Harga yang disepakati kedua pihak (pembeli dan penjual) haruslah jelas jumlah nominalnya.

$\checkmark$ Transaksi bisa diserahkan ketika akad, baik dengan uang tunai, cek, ataupun kartu kredit.

$\checkmark \quad$ Jika jual beli dilakukan dengan cara barter (tukar menukar sesama barang), maka bisa disesuaikan dengan barang yang memiliki nilai harga, kuantitas dan kualitas yang sama.

4. Ijab qabul (pernyataan jual beli) 
$\checkmark$ Ungkapan ijab qabul harus dibaca dengan jelas antara kedua belah pihak (penjual dan pembeli)

$\checkmark \quad$ Ijab dan qabul dilakukan satu majelis, artinya pembeli dan penjual harus dalam satu tempat yang sama.

$\checkmark$ Ungkapan ijab qabul boleh dilakukan secara lisan, tulisan, dan isyarat.

\section{Jual Beli Yang Dilarang dalam Islam}

Jual beli yang diharamkan pada dasarnya dikarenakan dua hal, yaitu barang yang diperjualbelikan termasuk kategori yang diharamkan oleh agama dan karena faktor caranya yang tidak sesuai atau dilarang dengan syariat Islam. Sebagaimana surah An-Nisa ayat 29 ysng berbunyi :

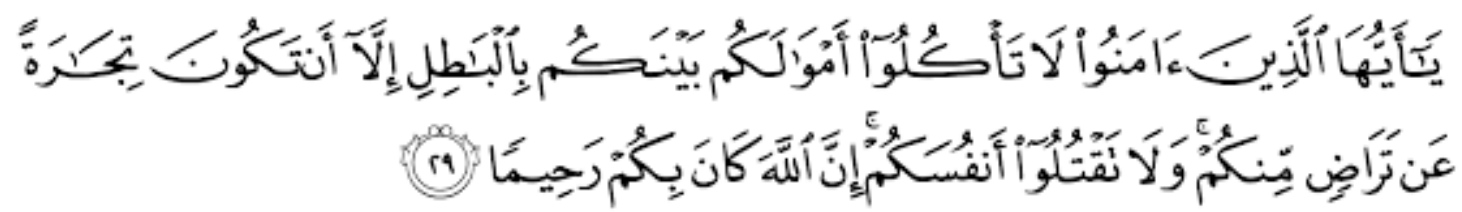

"Wahai orang-orang yang beriman! Janganlah kamu saling memakan harta sesamamu dengan jalan yang batil (tidak benar), kecuali dalam perdagangan yang berlaku atas dasar suka sama suka di antara kamu.”

Adapun dalam jual beli, Islam melarang melakukan kegiatan sebagai berikut :

- Menimbun barang

- Penipuan

- Adanya riba

- Menjual barang yang masih belum jelas

- Menjual sesuatu yang haram

- Pemalsuan barang

- Mempermainkan harga

- Mengurangi takaran dan timbangan

- Menjaul barang dari hasil curian 


\section{Agar Pelaksanaan Perdagangan Menjadi Adil}

Adil dalam bahasa arab yaitu Al-Adl dimana adil merupakan salah satu sifat yang harus dimiliki oleh setiap manusia di dunia, agar dapat menegakkan kebenaran dan tidak menimbulkan selisih paham sesama umat manusia. Adapun menurut ahli Al Ghozali adil adalah keseimbangan antara sesuatu yang lebih dan yang kurang, Menurut Ibnu Miskawaih keadilan adalah Memberikan sesuatu yang semestinya kepada orang yang berhak terhadap sesuatu itu.

Allah SWT berfirman: "Hai orang-orang yang beriman, jadilah kamu orang yang benar-benar menegakkan keadilan, menjadi saksi karena Allah biarpun terhadap dirimu sendiri atau ibu bapak dan kaum kerabatmu .” (An-Nisa': 135)

Di dalam Islam tentu saja sangat dianjurkan menerapkan perdagangan yang adil. Maksud dari perdagangan yang adil adalah tawar-menawar anatara penjual dan pembeli berlangsung dengan sempurna. Atau dengan perdagangan yang di mana si penjual dan si pembeli mendapatkan keuntungan yang sama. Tidak ada unsur penipuan atau rekayasa dalam segala hal, baik itu dalam harga atau barang. Serta tak adanya suatu paksaan dari kedua belah pihak yang bersangkutan.

Islam mempunyai arahan agar pelaksanaan jual berlangsung adil. Surah an-Nisa ayat 29 mengingatkan agar orang beriman tak saling memakan harta sesamanya dengan jalan batil, kecuali dengan perniagaan yang berlaku dengan suka sama suka di antara mereka. Maka itu, muncul ketetapan tentang batas keuntungan yang bisa diambil. Cendekiawan Muslim, Syekh Yusuf al-Qaradhawi, melihat adanya kaitan antara keuntungan dan al-ghaban atau taktik penawaran. Diakui bahwa di sebagian kalangan masalah ini masih dianggap samar.

Adapun di lingkup para ahli fikih sejak lama disepakati bahwa al-ghaban ditoleransi dengan batas maksimal sepertiga dari harga pembelian pokok. Sedangkan, apabila melebihi jumlah itu dianggap sebagai al-ghaban yang buruk serta tidak boleh dilakukan. Ini ditegaskan al-Qaradhawi dalam bukunya Fatwa-Fatwa Kontemporer. Lebih jauh dijelaskan, berdagang atau tijarah adalah membeli barang dagangan untuk dijual kembali. Tujuannya yakni agar memperoleh keuntungan atau laba. Seperti diungkapkan dalam surah ash-Shaf ayat 10: "Mereka itu mengharapkan perniagaan yang tidak akan merugi". 
Dalam menafsir ayat tersebut, al-Qaradhawi berpendapat bahwa perdagangan merupakan suatu usaha yang diridhai Allah SWT. Mereka yang melakukannya dipandang sedang mencari karunia Allah. Hanya saja, seberapa besar batasan keuntungan yang wajar itu lain soal.

Menurut Rasulullah, jelas dia, batas minimal yang boleh diperoleh yaitu sekiranya keuntungan itu dapat digunakan untuk membayar zakat modal hingga modal itu tidak termakan zakat. Selain itu juga cukup untuk menafkahi dirinya dan keluarganya. Sedangkan, batasan maksimalnya tidak ditentukan, bahkan bisa lebih dari 100 persen.

Ulama ternama ini mengungkapkan, ada beberapa dalil yang menunjukkannya. Namun diingatkan bahwa apa yang dipraktikkan pada masa awal Islam itu tidak dimaksudkan bahwa setiap perdagangan boleh memungut laba hingga batas itu. Terlebih bagi orang yang berdagang barang kebutuhan pokok dan sangat dibutuhkan masyarakat.

Pandangan senada diungkapkan ulama besar, Sayyid Sabiq. Melalui bukunya Fiqih Sunnah, dia bertutur bahwa mencari laba adalah wajar dalam berniaga. Asalkan tidak dilakukan dengan jalan menipu, menimbun, mengecoh, dan praktik tercela lainnya. Ia menggolongkan kecurangan itu sebagai keburukan.

Sebagian ulama lain menyatakan, baru bisa dikategorikan curang jika kuantitas barang mencapai sepertiga nilai harga. Praktik kecurangan yang sangat dicela yakni menimbun barang. Kata Sayyid Sabiq, hukumnya haram karena bersumber dari sifat tamak dan akhlak rendah. "Serta bisa merugikan kehidupan masyarakat banyak."

Ia mengatakan, sebuah hadis Nabi Muhammad SAW yang diriwayatkan oleh Abu Dawud, Tirmizi, dan Muslim perlu diperhatikan. "Barang siapa yang menimbun barang, ia telah berbuat kesalahan". Sabiq menjelaskan, menimbun barang dilakukan dengan membeli barang, lalu menyimpannya agar barang itu berkurang di pasaran. Langkah ini kemudian menyebabkan harga barang itu menjadi mahal. Menurut Sabiq, penimbunan barang tak menjadi soal bila barang itu tak dibutuhkan masyarakat.

\section{PENUTUP}

Kesimpulan yang dapat ditarik dari artikel di atas adalah :

Perdagangan atau jual beli merupakan hal yang sudah ada dari zaman dahulu kala. Bahkan perdagangan adalah jalur yang digunakan untuk menyebarkan agama Islam. Perdagangan 
adalah kegiatan tukar menukar barang atau jasa atau keduanya yang berdasarkan kesepakatan bersama bukan pemaksaan. Ada satu prinsip dagang yang terkenal. Dengan modal sekecilkecilnya, meraih keuntungan sebesar-besarnya. Maka tidak mengherankan, demi mengejar keuntungan yang besar, apa pun akan dilakukan. Bahkan, sebagian pelaku perdagangan bersedia melanggar ketentuan hukum. Sifat adil merupakan sifat yang sangat disukai oleh Allah swt. Sifat adil juga membuat kita menegakkan kebenaran yang ada sehingga tidak terjadi yang namanya kebencian atau selisih paham dalam hidup. Untuk itu sangat penting untuk melakukan sebuah perdagangan yang adil dalam Islam. Dengan menerapkan perdagangan yang adil kita akan selalu diridhoi bahkan diberkahi oleh Allah dalam melakukannya. Dengan begitu kegiatan jual beli yang dilakukan akan berjalan dengan baik.

\section{DAFTAR PUSTAKA}

Drs. Harun, M. (2017). Fiqh Muamalah. Surakarta: Muhammadiyah University Press.

Imam. (2020, April 8). Syarat Jual Beli dalam Islam agar Transaksi Sah dan Sesuai Syariah. Dipetik Juli 7, 2021, dari 99.co: https://www.99.co/id/panduan/syarat-jual-beli

Muslihin. (2012, Desember 28). Definisi Perdagangan Dalam Islam. Dipetik Juli 7, 2021, dari Referensi Makalah: https://www.referensimakalah.com/2012/12/definisiperdagangan-dalam-islam.html

Sasongko, A. (2017, Februari 1). Agar Pelaksanaan Jual Beli Berlangsung Adil. Dipetik Juli 7, 2021, dari Republika: https://www.republika.co.id/berita/duniaislam/fatwa/17/02/01/okp8kf313-agar-pelaksanaan-jual-beli-berlangsung-adil

Taufiq. (2016). Etika Perdagangan Dalam Islam. Al-Muamalat Jurnal Hukum Ekonomi Syariah, III(01), 112-123.

Wikipedia. (2019, Oktober 29). Perdagangan. Dipetik Juli 7, 2021, dari Wikipedia: https://id.wikipedia.org/wiki/Perdagangan 